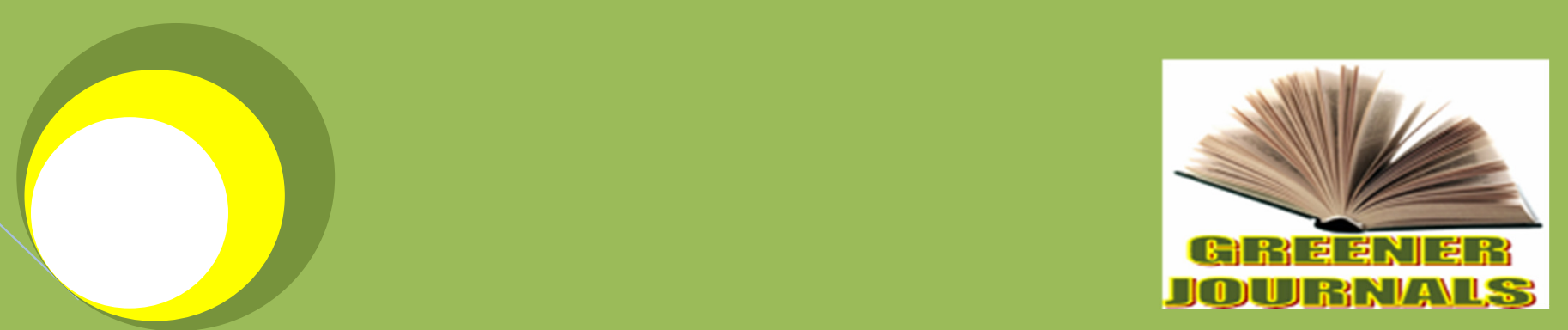

Greener loumal of Medical Sciences

ISSN: 2276-7797 ICV: $\mathbf{5 . 9 8}$

Submitted: $27 / 02 / 2017$

Accepted: 04/03/2017

Published: 28/03/2017

DOI: http://doi.org/10.15580/GJMS.2017.2.022717028

Effect of Aqueous Leaf Extract of Ocimum Gratissimum on some Haematological Indices in Rats Treated with Zidouudine-containing Antiretroviral Drugs

By

Ughachukwu PO

Okonkwo PO

Nwozor CM

Okafor IJ

Nwafia IN

Ochiogu BC 


\title{
Effect of Aqueous Leaf Extract of Ocimum Gratissimum on some Haematological Indices in Rats Treated with Zidovudine-containing Antiretroviral Drugs
}

\section{Ughachukwu PO*1, Okonkwo PO', Nwozor CM², Okafor IJ³, Nwafia IN ${ }^{4}$, Ochiogu BC $^{5}$}

\footnotetext{
${ }^{1}$ Department of Pharmacology and Therapeutics,College of Medicine, Chukwuemeka Odumegwu Ojukwu University.

${ }^{2}$ Department of Human Physiology, College of Medicine, Chukwuemeka Odumegwu Ojukwu University.

${ }^{3}$ Department of Anatomy,College of Medicine, Chukwuemeka Odumegwu Ojukwu University.

${ }^{4}$ Department of Medical Microbiology,College of Medicine, Chukwuemeka Odumegwu Ojukwu University.

${ }^{5}$ Department of Ophthalmology, College of Medicine, Chukwuemeka Odumegwu Ojukwu University.

*Corresponding Author’s Email: ughapieces@yahoo. com; Phone: +2348061146275
}

\begin{abstract}
Background: Anaemia, one of the manifestations of HIV/AIDS, could be worsened by zidovudine-containing antiretroviral therapy. This may result in discontinuation of therapy, drug resistance, and increased mortality and morbidity. The medicinal plant, Ocimum gratissimum, is credited with haematopoetic properties. The study is aimed at finding out if the leaf extract of this plant will protect against anaemia in zidovudine-containing antiretroviral therapy. Methodology: 25 adult rats of both sexes were divided into 5 groups (A, B C, D, E) of 5 animals per group and given oral antiretroviral drugs and extract as follows: A (normal feeds only), B (efavirenz $8.6 \mathrm{mg} / \mathrm{kg}$, abacavir $8.6 \mathrm{mg} / \mathrm{kg}$, zidovudine $4.3 \mathrm{mg} / \mathrm{kg}$ ), C (extract $80 \mathrm{mg} / \mathrm{kg}$ ), D (efavirenz $8.6 \mathrm{mg} / \mathrm{kg}$, abacavir $8.6 \mathrm{mg} / \mathrm{kg}$, zidovudine $4.3 \mathrm{mg} / \mathrm{kg}$, plus extract $40 \mathrm{mg} / \mathrm{kg}$ ), E (efavirenz $8.6 \mathrm{mg} / \mathrm{kg}$, abacavir $8.6 \mathrm{mg} / \mathrm{kg}$, zidovudine $4.3 \mathrm{mg} / \mathrm{kg}$, plus extract $80 \mathrm{mg} / \mathrm{kg}$ ) all for 28 days. Thereafter, blood samples were collected and analyzed for haemoglobin and packed cell volume values using autoanalyzer. Data were tested for normality and further analyzed for statistical significance using Kruskal-Wallis test plus Dunn's multiple comparison using Graph Pad Prism 7.0. Results: Mean values ( \pm S.E.M.) of haemoglobin were 12.7 $\pm 0.7,13.7 \pm 0.8,11.6 \pm 1.4,12.2$ \pm 1.7 , and $13.9 \pm 1.0$ for groups A, B, C, D, and E respectively. Mean values ( \pm S.E.M.) of Packed Cell Volume (PCV) are $38.2 \pm 2.2,41.4 \pm 2.2,35.0 \pm 4.1,36.8 \pm 4.9$, and $41.3 \pm 3.0$ for groups $A, B, C, D$, and E respectively. Dunn's multiple comparison test did not yield any statistically significant differences $(P$ values 0.7368 and 0.7325 for haemoglobin and PCV values respectively). Conclusion: The results show that neither antiretroviral drugs nor extract affected the haemoglobin level or the PCV in the rats during the course of this experiment.
\end{abstract}

Key words: Antiretroviral drugs, haemoglobin, ocimum gratissimum, rats, zidovudine.

\section{INTRODUCTION}

Bone marrow suppression characterized by abnormal haematological indices is one of the serious adverse effects of antiretroviral drugs, especially the nucleoside reverse transcriptase inhibitors (Renner et al., 2013). Anaemia, one of the commonest manifestations of bone marrow suppression, often resolves when treatment is initiated with antiretroviral drugs (Kerkhoff et al., 2014). However, this anaemia could get worse if nucleoside reverse transcriptase inhibitors, especially zidovudine, are components of the antiretroviral regimen. In a study, Curkendall et al. found that HIV patients initiating zidovudine-containing antiretroviral regimen were at greater risk of developing anaemia or worsening of existing ones than patients initiating non-zidovudine-containing regimen Curkendal et al., 2007).

This often results in discontinuation of treatment and worsening of the patient's condition (Nunez, 2006). Discontinuation of antiretroviral treatment worsens drug resistance which is also very common with these agents. This invariably contributes to increased incidence of hospital admission. Prevention of ART-induced anaemia will, therefore, contribute positively to effective treatment of HIV/AIDS patients. 
The most important treatment of drug-induced hematologic disorders is removal of the offending drug and supportive care of the patient (Rao, 2014). Pharmacological methods of ameliorating drug-induced anaemia include the use of folic acid, corticosteroids, rituximab (a humanized monoclonal antibody), recombinant human erythropoietin (rHu Epo), and human granulocyte/monocyte colony stimulating factor (Matsumoto et al., 1990; Somogyi et al., 1996; Dietrickx et al., 2015). However, some of these drugs appear ineffective and may even present their own problems. Besides, some of them are very costly especially when some are to be taken for a long time before the manifestation of their beneficial effects.

Ocimum gratissimum is a vegetable that is edible, so the chances of it being toxic are minimal. In fact, it has been demonstrated that its extract, when administered to albino rats for 28 days at a dose of $80 \mathrm{mg} / \mathrm{kg}$ did not result in any toxic effect to the liver (Ughachukwu et al., 2016). This plant, also known as scent leaf (nchuanwuin lgbo) belongs to the family Lamiaceaae and is commonly used in the treatment of fever, diarrhoea, dysentery, pile, and convulsions (Prabhu et al., 2009). Previous phytochemical studies on this plant revealed the presence of alkaloids, phytates, tannins, flavonoids, and oligosaccharides (Maria et al., 2004).

\section{Justification for the study}

There is high incidence and prevalence of zidovudine-containing anti-retroviral induced anaemia. This anaemia, when moderate or severe, may warrant discontinuation of antiretroviral therapy with the attendant increase in hospital stay, increase in the cost of treatment, and increase in morbidity and mortality. The disruption of therapy also encourages the emergence of resistant strains of HIV which increases the prevalence of HIV/AIDS and the resultant public health concerns. Previous studies had shown that the aqueous leaf extract of Ocimum gratissimum when taken orally over a one month period increased the haemoglobin level in rats (Shehu et al., 2012; Ofem et al., 2012). It was therefore suggested that the combination of this herb with antiretroviral drugs could reduce the incidence of anaemia associated with the nucleoside reverse transcriptase inhibitors especially zidovudine.

\section{OBJECTIVES OF THE STUDY}

The main objective of the study is to determine if the aqueous leaf extract of O.gratissimum has a protective effect on haematological indices in zidovudine-containing ART-treated rats. Specific objectives include:

a. To determine the effect of abacavir, efavirenz, and zidovudine on haemoglobin level and PCV in rats.

b. To determine the effect of aqueous leaf extract of O.gratissimum on haemoglobin level and PCV in rats.

c. To determine the effect of aqueous leaf extract of O.gratissimum on haemoglobin level and PCV in zidovudine-containing ART-treated rats.

\section{Hypotheses}

The Null hypothesis states that aqueous leaf extract of $O$. gratissimum does not decrease haemoglobin level and PCV in zidovudine-containing ART-treated rats. The alternative hypothesis states that aqueous leaf extract of $O$. gratissimum decreases haemoglobin level and PCV in ART-treated rats. The null hypothesis would be tested at a significant level ( $p$ value) of 0.05 . It would be rejected if the $p$ value is $<0.05$ and accepted if $p$ value $>0.05$. At $p$ value $<0.05$, the null hypothesis would be rejected implying that aqueous leaf extract of $O$. gratissimum decreases haemoglobin level and PCV in zidovudine-containing ART-treated rats.

\section{MATERIALS AND METHODS}

This study was conducted at the Pharmacology laboratory, Department of Pharmacology and Therapeutics, College of Medicine, ChukwuemekaOdumegwuOjukwu University,Awka Campus.

2.1 Calculation of sample size: Sample size $[\mathrm{N}]$ of 25 rats at $95 \%$ power to detect a difference between means of 2.5 at a significant level (alpha) of 0.05 (two tailed) was chosen using the special formula for the calculation of sample size for laboratory animal experiments (NRC, 2003):

$$
N=1+2 C[s / d]^{2}
$$


Where, $\mathrm{C}=\mathrm{a}$ constant [7.8] at 0.05 level of significance; $\mathrm{s}=2.75$ [standard deviation from a similar previous study] (Youm et al., 2010); $d$ = difference between means desired in present study.

2.2 Animal source: Twenty five (25) rats of both sexes, 6-8 weeks old, were obtained from the animal house, Department of Pharmacology and Therapeutics, Chukwuemeka Odumegwu Ojukwu University, Awka Campus, Nigeria. The animals were certified healthy by a veterinarian. Each group of 5 rats was housed in a metal cage measuring $60 \mathrm{~cm} \times 45 \mathrm{~cm} \times 30 \mathrm{~cm}$ and was allowed free access to animal feeds (Growers, Top Feeds, Nigeria) and clean drinking water. Left over feeds and water were discarded and the cages cleaned with chlorhexidine antiseptic solution every 12 hours. Artificial light was provided by fluorescent lamp (Philips, Holland; 18 watts) and light-dark cycle of 12-12 hours maintained. The animals were maintained in this arrangement for two weeks for acclimatization.

2.3 Preparation of plant extracts: Two (2) kilogrammes of fresh leaves of O.gratissimumwas collected, washed under running tap water, and air-dried at room temperature. Thereafter, the dried leaves were ground into fine powder and 50 grammesof the powder were extracted with $500 \mathrm{ml}$ of distilled water using the Soxhlet method (Pirie, 1975). The filtrate was obtained by solvent evaporation.

2.4 Experimental procedure: The rats were randomly divided into 5 groups of 5 each. Thereafter, we treated the animals with the following drugs by gastric gavage for 28 days (Sule et al., 2012) as follows:

Group A: Each rat was given normal feed (no ART, no extract)

Group B: Each rat was given efavirenz(Ranbaxy, India) $8.6 \mathrm{mg} / \mathrm{kg}$, abacavir (Ranbaxy, India) $8.6 \mathrm{mg} / \mathrm{kg}$, and zidovudine (Ranbaxy, India) $4.3 \mathrm{mg} / \mathrm{kg}$ (Kayode et al., 2011).

Group C: Each rat was given $80 \mathrm{mg} / \mathrm{kg}$ aqueous leaf extract of $O$. gratissimum.

Group D: Each rat was given efavirenz $8.6 \mathrm{mg} / \mathrm{kg}$, abacavir $8.6 \mathrm{mg} / \mathrm{kg}$, and zidovudine $4.3 \mathrm{mg} / \mathrm{kg}$, plus $40 \mathrm{mg} / \mathrm{kg}$ aqueous leaf extract of $O$. gratissimum (Uhegbu et al., 2012).

Group E: Each rat was given efavirenz $8.6 \mathrm{mg} / \mathrm{kg}$, abacavir $8.6 \mathrm{mg} / \mathrm{kg}$, and zidovudine $4.3 \mathrm{mg} / \mathrm{kg}$, plus $80 \mathrm{mg} / \mathrm{kg}$ aqueous leaf extract of $O$. gratissimum.

A treatment chart was maintained. After 28 days, blood samples were collected from each rat for the estimation of haemoglobin and PCV.

2.5 Collection of blood samples: The rats were anaesthetized, one at a time, using intramuscular ketamine (Nirma, India) and diazepam (Norris Medicals, India) $50 \mathrm{mg} / \mathrm{kg}$ and $5 \mathrm{mg} / \mathrm{kg}$ respectively (RAR, 2009). Thereafter, blood samples were collected using the method described byHoff (2000). Briefly, the skin over the jugular vein was cleaned with methylated spirit-soaked cotton wool and 1.0-1.5 mls of whole blood withdrawn through the jugular vein using a 25G hypodermic needle fitted unto a $2 \mathrm{ml}$ syringe. The withdrawn blood samples was transferred gently into heparinized specimen bottles, stored at $2-8^{\circ} \mathrm{C}$, and analyzed within 24 hours for haemoglobin concentration $(\mathrm{Hb})$ and packed cell volume (PCV) using Haematology Autoanalyser (Erma Inc, PCE-210).

2.6 Statistical analysis: The mean values ( \pm S.E.M.) of HB and PCV were calculated. Then the data were tested for normality using D'Augostino and Pearson omnibus normality test. Thereafter, values of HB and PCV obtained for the test and control groups of rats were tested for statistically significant differences using Kruskal-Wallis test plus Dunn's multiple comparisons. There was no transformation of data. All the statistical tests were performed using Graph Pad Prism 7.0 and the results taken as statistically significant if the p value $<0.05$.

\subsection{RESULTS}

The mean values $( \pm$ S.E.M.) of the haemoglobin concentration $(\mathrm{HB})$ were $12.7 \pm 0.7,13.7 \pm 0.8,11.6 \pm 1.4,12.2 \pm 1.7$, and $13.9 \pm 1.0$ for groups A, B, C, D, and E respectively (Table 1). The mean values ( \pm S.E.M.) of Packed Cell volume (PCV) are 38.2 $\pm 2.2,41.4 \pm 2.2,35.0 \pm 4.1,36.8 \pm 4.9$, and $41.3 \pm 3.0$ for groups $\mathrm{A}, \mathrm{B}, \mathrm{C}, \mathrm{D}$, and $\mathrm{E}$ respectively (Table 2). Kruskal-Wallis test followed by Dunn's multiple comparison performed on the values of HB and PCV for the groups did not yield any statistically significant differences as shown in Figures 1, 2, 3, and 4 (P values 0.7368 and 0.7325 for haemoglobin and PCV values respectively). 
Table 1: Mean ( \pm S.E.M) haemoglobin $(\mathrm{g} / \mathrm{dl})$ in the test and control groups of rats

\begin{tabular}{|l|l|l|l|l|}
\hline Group $A\left(\mathrm{~A}_{1}-\mathrm{A}_{5}\right)$ & Group B $\left(\mathrm{B}_{1}-\mathrm{B}_{5}\right)$ & Group $\mathrm{C}\left(\mathrm{C}_{1}-\mathrm{C}_{4}\right)$ & Group $\mathrm{D}\left(\mathrm{D}_{1}-\mathrm{D}_{4}\right)$ & Group $\mathrm{E}\left(\mathrm{E}_{1}-\mathrm{E}_{4}\right)$ \\
\hline 13.3 & 11.6 & 8.6 & 15.3 & 13.0 \\
\hline 14.3 & 14.0 & 10.3 & 10.6 & 16.6 \\
\hline 12.6 & 13.6 & 15.0 & 8.3 & 14.0 \\
\hline 13.4 & 13.0 & 12.4 & 14.6 & 12.0 \\
\hline 10.0 & 16.3 & ---- & ---- & ---- \\
\hline Mean $12.7 \pm 0.7$ & $13.7 \pm 0.8$ & $11.6 \pm 1.4$ & $12.2 \pm 1.7$ & $13.9 \pm 1.0$ \\
\hline
\end{tabular}

Table 2: Mean ( \pm S.E.M) packed cell volume (\%) in the test and control groups of rats

\begin{tabular}{|l|l|l|l|l|}
\hline Group A $\left(\mathrm{A}_{1}-\mathrm{A}_{5}\right)$ & Group B $\left(\mathrm{B}_{1}-\mathrm{B}_{5}\right)$ & Group C $\left(\mathrm{C}_{1}-\mathrm{C}_{4}\right)$ & Group D $\left(\mathrm{D}_{1}-\mathrm{D}_{4}\right)$ & Group E $\left(\mathrm{E}_{1}-\mathrm{E}_{4}\right)$ \\
\hline 40 & 35 & 26 & 46 & 39 \\
\hline 43 & 42 & 31 & 25 & 50 \\
\hline 38 & 41 & 45 & 35 & 42 \\
\hline 40 & 40 & 38 & 44 & 36 \\
\hline 30 & 49 & ---- & ---- & ---- \\
\hline Mean 38.2 \pm 2.2 & $41.4 \pm 2.2$ & $35.0 \pm 4.1$ & $36.8 \pm 4.9$ & $41.8 \pm 3.0$ \\
& & & & \\
\hline
\end{tabular}

\section{DISCUSSION}

The results show that neither antiretroviral drugs nor aqueous leaf extract of Ocimum gratissimum increased or reduced the haemoglobin level or the PCV in the rats during the course of the experiment. The findings agree with that of Ikeh who found that this extract did not protect against cyclophosphamide-induced bone marrow suppression in albino rats (Ikeh, 2013). However, the findings contrast with those from some earlier studies. For instance, Ukoha et al. (2015) found that zidovudine at a dose of $0.8 \mathrm{mg} / \mathrm{kg}$ for 28 days significantly reduced the haemoglobin level and PCV in adult rats. Also other studies found that these two haematologic indices were significantly increased in adult rats that were fed with the extracts of $O$. gatissimum for 28 days (Shehu et al., 2012; Ofem et al., 2012). These differences in results could be as a result of differences in the dosage of extracts used. For example, this study used a maximum dose of $80 \mathrm{mg} / \mathrm{kg}$ whereas these earlier authors used $1000 \mathrm{mg} / \mathrm{kg}$. Also, the addition of the extract of $O$. gratissimum to the antiretroviral regimen may have affected the propensity of zidovudine to reduce the heamoglobin and PCV even though group $C$ rats (extract alone) did not record higher haemoglobin and PCV values. Other factors could also be responsible for the differences in the results. For instance, the age of plant at harvest, soil characteristics, and other environmental variables affect the active constituents of medicinal plants (Evans, 2002). 


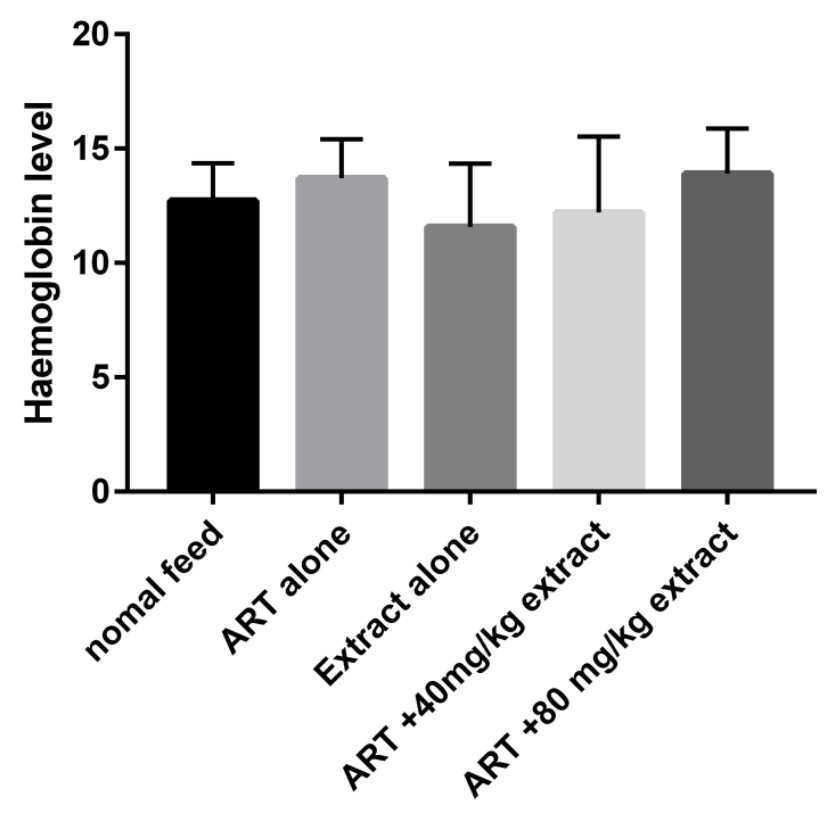

Rat groups A, B, C, D, E

\begin{tabular}{|l|l|}
\hline & \\
\hline Table Analyzed & Data 1 \\
\hline Kruskal-Wallis test & \\
P value & 0.7368 \\
Exact or approximate P value? & Approximate \\
P value summary & ns \\
Do the medians vary signif. $(\mathrm{P}<0.05) ?$ & No \\
Number of groups & 5 \\
Kruskal-Wallis statistic & 1.994 \\
& \\
Data summary & \\
Number of treatments (columns) & 5 \\
Number of values (total) & 22 \\
\hline
\end{tabular}

Figure 1: Haemoglobin (HB) values of rats treated with antiretroviral drugs (ART) alone (Group B) compared with those of group A (no extract, no ART), group C (extract alone), group D (ART + $40 \mathrm{mg} / \mathrm{kg}$ extract), and group E (ART + $80 \mathrm{mg} / \mathrm{kg}$ extract) using Kruskal-Wallis test 


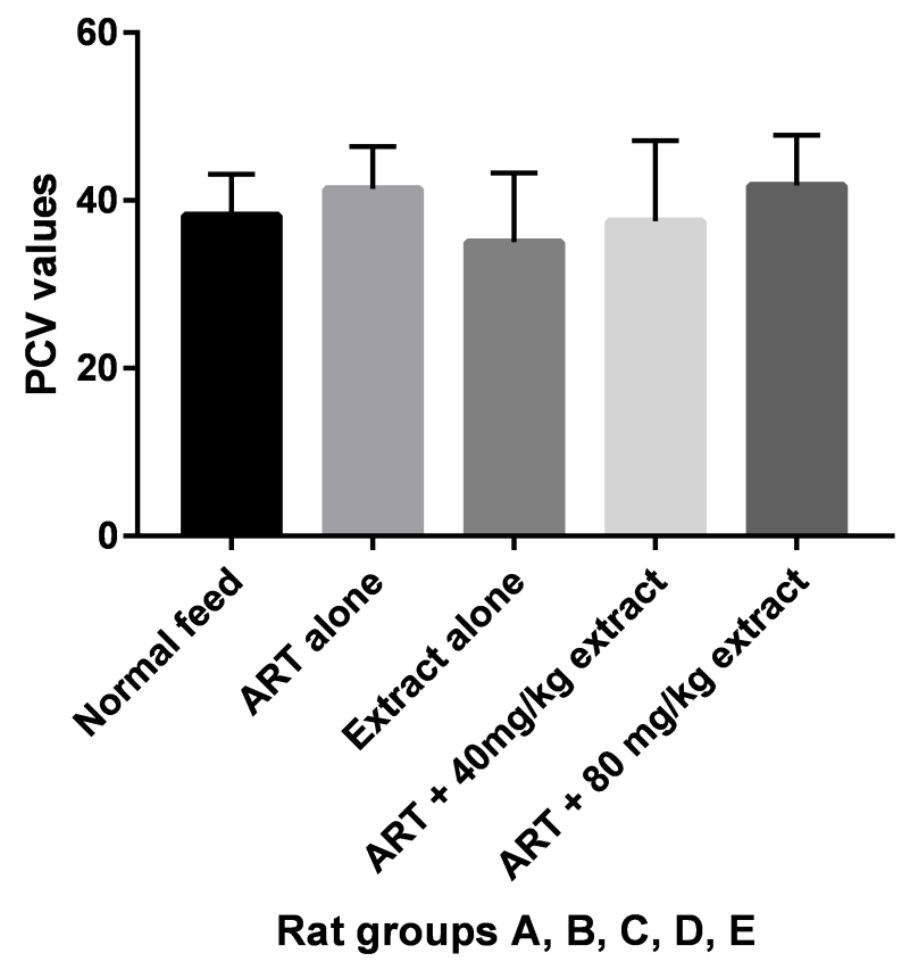

\begin{tabular}{|l|l|}
\hline & \\
\hline Table Analyzed & Data 1 \\
Kruskal-Wallis test & \\
P value & 0.7325 \\
Exact or approximate P value? & Approximate \\
P value summary & ns \\
Do the medians vary signif. $(\mathrm{P}<0.05) ?$ & $\mathrm{No}$ \\
Number of groups & 5 \\
Kruskal-Wallis statistic & 2.018 \\
& \\
Data summary & \\
Number of treatments (columns) & 5 \\
Number of values (total) & 22 \\
\hline
\end{tabular}

Figure 2: Packed cell volume (PCV) values of rats treated with antiretroviral drugs (ART) alone (Group B) compared with those of group A (no extract, no ART), group C (extract alone), group D (ART $+40 \mathrm{mg} / \mathrm{kg}$ extract), and group $E$ (ART $+80 \mathrm{mg} / \mathrm{kg}$ extract) using Kruskal-Wallis test 


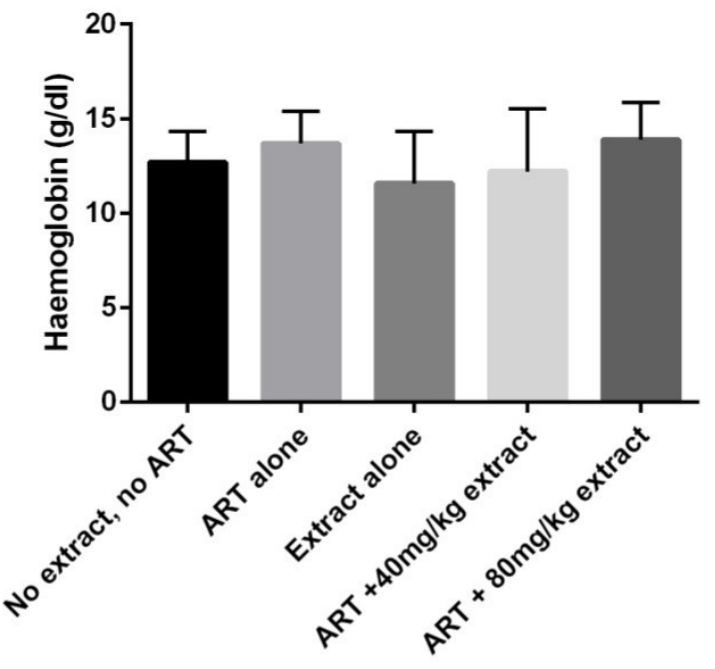

$A$ vs $B$ vs $C$ vs $D$ vs $E$

\begin{tabular}{|c|c|c|c|c|c|c|}
\hline & & & & & & \\
\hline Number of families & 1 & & & & & \\
\hline Number of comparisons per family & 4 & & & & & \\
\hline Alpha & 0.05 & & & & & \\
\hline Dunn's multiple comparisons test & Mean rank diff. & Significant? & Summary & & B-? & \\
\hline ART alone vs. No extract, no ART & 2.600 & No & ns & & A & No extract, no ART \\
\hline ART alone vs. Extract alone & 5.150 & No & ns & & C & Extract alone \\
\hline ART alone vs. ART $+40 \mathrm{mg} / \mathrm{kg}$ extract & 2.400 & No & ns & & D & ART $+40 \mathrm{mg} / \mathrm{kg}$ extract \\
\hline ART alone vs. ART $+80 \mathrm{mg} / \mathrm{kg}$ extract & -0.3500 & No & ns & & $\mathrm{E}$ & ART $+80 \mathrm{mg} / \mathrm{kg}$ extract \\
\hline Test details & Mean rank 1 & Mean rank 2 & Mean rank diff. & $\mathrm{n} 1$ & $\mathrm{n} 2$ & \\
\hline ART alone vs. No extract, no ART & 13.40 & 10.80 & 2.600 & 5 & 5 & \\
\hline ART alone vs. Extract alone & 13.40 & 8.250 & 5.150 & 5 & 4 & \\
\hline ART alone vs. ART $+40 \mathrm{mg} / \mathrm{kg}$ extract & 13.40 & 11.00 & 2.400 & 5 & 4 & \\
\hline ART alone vs. ART $+80 \mathrm{mg} / \mathrm{kg}$ extract & 13.40 & 13.75 & -0.3500 & 5 & 4 & \\
\hline
\end{tabular}

Figure 3: Haemoglobin (HB) values of rats treated with antiretroviral drugs (ART) alone (Group B) compared with those of group A (no extract, no ART), group C (extract alone), group D (ART + 40 $\mathrm{mg} / \mathrm{kg}$ extract), and group $E$ (ART $+80 \mathrm{mg} / \mathrm{kg}$ extract) using Dunn's multiple comparison test 


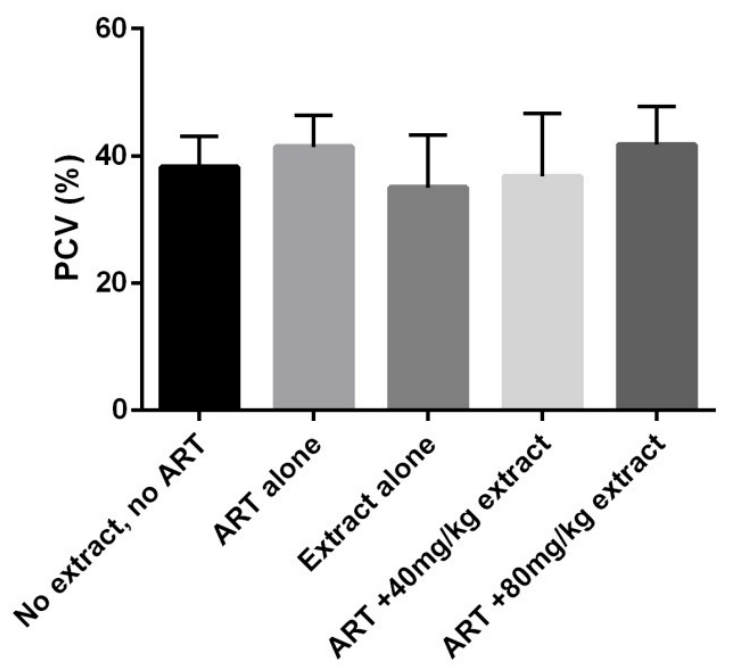

$A$ vs $B$ vs $C$ vs $D$ vs $E$

\begin{tabular}{|c|c|c|c|c|c|c|}
\hline & & & & & & \\
\hline Number of families & 1 & & & & & \\
\hline Number of comparisons per family & 4 & & & & & \\
\hline Alpha & 0.05 & & & & & \\
\hline Dunn's multiple comparisons test & Mean rank diff. & Significant? & Summary & & B-? & \\
\hline ART alone vs. No extract, no ART & 3.200 & No & ns & & A & No extract, no ART \\
\hline ART alone vs. Extract alone & 5.325 & No & ns & & C & Extract alone \\
\hline ART alone vs. ART $+40 \mathrm{mg} / \mathrm{kg}$ extract & 2.700 & No & ns & & $\mathrm{D}$ & ART $+40 \mathrm{mg} / \mathrm{kg}$ extract \\
\hline ART alone vs. ART $+80 \mathrm{mg} / \mathrm{kg}$ extract & 0.0750 & No & ns & & $E$ & ART $+80 \mathrm{mg} / \mathrm{kg}$ extract \\
\hline Test details & Mean rank 1 & Mean rank 2 & Mean rank diff. & $\mathrm{n} 1$ & $\mathrm{n} 2$ & \\
\hline ART alone vs. No extract, no ART & 13.70 & 10.50 & 3.200 & 5 & 5 & \\
\hline ART alone vs. Extract alone & 13.70 & 8.375 & 5.325 & 5 & 4 & \\
\hline ART alone vs. ART $+40 \mathrm{mg} / \mathrm{kg}$ extract & 13.70 & 11.00 & 2.700 & 5 & 4 & \\
\hline ART alone vs. ART $+80 \mathrm{mg} / \mathrm{kg}$ extract & 13.70 & 13.63 & 0.0750 & 5 & 4 & \\
\hline
\end{tabular}

Figure 4: Packed cell volume (PCV) values of rats treated with antiretroviral drugs (ART) alone (Group B) compared with those of group A (no extract, no ART), group C (extract alone), group D (ART + $40 \mathrm{mg} / \mathrm{kg}$ extract), and group E (ART + $80 \mathrm{mg} / \mathrm{kg}$ extract) using Dunn's multiple comparison test

Also, possible genetic differences between the groups of rat and those used in earlier studies could also be contributory.

The ability of the rats to maintain normoglobinaemia during the cause of antiretroviral therapy despite the inclusion of zidovudine in the ART regimen was unexpected since zidovudine is credited with the highest tendency to cause anaemia (Agarwal et al., 2010). The reason could be because the rats were not having HIV infection which usually has anaemia as one of its cardinal symptoms. Besides, it takes as long as six months for the effect of antiretroviral drugs on haemoglobin level to become evident (Daka et al., 2013). Therefore, for any agent to increase or reduce haemoglobin level, that agent must necessarily be present for a long enough period of time to affect erythropoietin production. In this study, the rats were treated with the drugs for only 28 days.

Reduced erythropoietin production appears to be pivotal to the anaemia of HIV infection (Renner et al., 2013; Tadele, 2014), but there is no direct evidence linking zidovudine-induced anaemia with reduced plasma erythropoietin levels. However, zidovudine causes megaloblastic anaemia by direct toxicity to the erythroid and myeloid cell lines in the bone marrow. This reversible toxicity is observed within 3-6 months of treatment (Anonymous, 2010). Interestingly, zidovudine-induced anaemia responds very well to the administration of erythropoietin and recombinant granulocyte-macrophage colony stimulating factor (Rang et al., 2003). This suggests 
that zidovudine decreases plasma levels of erythropoietin. Therefore, it seems logical that zidovudine-induced anaemia can be ameliorated only by agents that enhance erythropoietin production. However, there is no literature evidence that $O$. gratissimum increases plasma erythropoietin level, a fact that further supports the findings in this study.

\section{CONCLUSIONS}

In this study, neither the zidovudine-containing antiretroviral regimen nor the extract of $O$. gratissimum affected the haemoglobin or PCV values in the experimental animals. The statistical findings show that there were no statistically significant differences in haemoglobin and PCV values between the exposed and control groups of rats. Consequently, the null hypothesis was accepted and the alternative hypothesis rejected. Therefore, it could be concluded that at the doses and length of exposure used in this study, aqueous leaf extract of Ocimum gratissimum and zidovudine-containing ART regimen did not affect the haemoglobin and PCV values in rats. These unexpected findings could be due to differences in the dosage of extract used, possible variations in the active constituents of the plant extract, possible differences in the genetic make-up of the animals, and the fact that the animals were not HIV models. Future studies on this subject matter should take the above factors into consideration.

\section{REFERENCES}

Agarwal D, Chakravarty J, Chaube L, Rai M, Agarwal NR, Sundar S (2010). High incidence of zidovudine induced anaemia in HIV infected patients in eastern India. Indian J Med Res 132: 386-389.

Anonymous. Zidovudine-induced anaemia in HIV/AIDS. Commentary (2010).Indian J Med Res 132: 359-361. Available at: http://medind.nic.in/iby/t10/i10/ibyt10i10p359.pdf (Accessed 1 August 2016).

Curkendall S, Richardson J, Emons M, Fisher A, Everhard F (2007). Incidence of anaemia among HIV-infected patients treated with highly active antiretroviral therapy. HIV Medicine 8: 483-490.

Daka D, Lelissa D, Amsalu A (2013). Prevalence of anaemia before and after the initiation of antiretroviral therapy at ART Centre of Hawassa University Referral Hospital, Hawassa, South Ethiopia. Scholarly Journal of Medicine $3(1): 1-6$.

Dierickx D, Kentos A, Delannoy A (2015). The role of rituximab in adults with warm antibody autoimmune hemolytic anemia. Blood 125 (21): 3223-9.

Evans WC (2002). Trease and Evans Pharmacognosy. $15^{\text {th }}$ ed. London: W.B. Saunders; 61.

Kerkhoff AD, Wood R, Cobelens FG, Gupta-Wright A, Bekker L-G, Lawn SD (2014). Resolution of anaemia in a cohort of HIV-infected patients with a high prevalence and incidence of tuberculosis receiving antiretroviral therapy in South Africa. BMC Infect Dis 14: 3860.

Hoff $J$ (2000). Methods of blood collection in the mouse. Lab Animal 29(10): 47-53.

Ikeh C (2013). Protective role of aqueous leaf extract of Vernonia amygdalina del. (asteraceae) and O.cimum gratissimumlinn (lamiaceae) in cyclophosphamide induced urotoxicity and myelosuppression .MSc. Thesis. University of Nigeria, Nsukka. pp.82-85.

Kayode AAA, Kayode OT, Aroyeun OA, Stephen MC 92011). Haematologic and hepatic enzyme alterations associated with acute administration of antiretroviral drugs. J Pharmacol Toxicol 6: 293-302.

Maria GVS, Francisco JAM, Paulo ROL, Fábio OS, Márcio TH (2004). Composition of essential oils from three Ocimum species obtained by steam and microwave distillation and supercritical $\mathrm{CO}$ extraction. ARKIVOC 6: 6671.

Matsumoto T, Endoh K, Kamisango K, Akamatsu K, Koigumi K, Higuchi M, Imai N, Mitsui H, Kawaguchi T (1990). Effect of recombinant human erythropoietin on anticancer drug-induced anaemia. BJH 75(4): 463-468.

National Research Council, NRC (2003). Guidelines for the Care and Use of Mammals in Neuroscience and Behavioral Research. Washington (DC): Academies Press (US); A Sample Size Determination. Available:http://www.ncbi.nlm.nih.gov/books/NBK43321/. (Accessed 21 August 2015).

Nunez M (2006). Hepatotoxicity of antiretrovirals: Incidence, mechanisms, and management. Journal of Hepatology 44(1): S132-S139.

Ofem O, Ani E, Eno A (2012). Effect of aqueous leaves extract of Ocimum gratissimum on hematological parameters in rats. Int J Appl Basic Med Res 2(1): 38-42.

Pirie NW (1975). Leaf protein; a beneficiary of tribulation. Nature 253: 239-243.

Prabhu KS, Lobo R, Shirwaikar AA, Shirwaikar A (2009). Ocimum gratissimum: A review of its chemical, pharmacological and ethnomedicinal properties. The Open Complementary Medicine 1: 1-15.

Rang HP, Dale MM, Ritter JM, Moore PK (2003). Pharmacology. $5^{\text {th }}$ ed. Philadelphia: Churchill Livingstone. 
Rao KV (2014). Drug-induced haematologic disorders. Pharmacotherapy. Available at: http://www.mhpharmacotherapy.com/0071800530/online_pdfs/24_Dipi_Web_Ch24_359-374.pdf (Accessed1 August 12016 ).

Research Animal Resources, RAR (2009). Guidelines for the use of anaesthetics, nalgesics and tranquilizers in laboratory animals. Available at: http://www.ahc.umn.edu/rar/anes thesia.html. (Accessed 20 September 2015).

Renner LA, Dicko F, Koueta F, Malateste K, Gueye RD, Aka E, Eboua T, Azondekon A, Okomo U, Toure P, Ekouevi D, Leroy V(2013). Anaemia and zidovudine-containing antiretroviral therapy in paediatric antiretroviral programmes in the leDEA paediatric West African Database to evaluate AIDS. JIAS 16: 18024.

Shehu A, Umana UE, Timbuak JA, Hamman QW, Musa SA, Ikyembe DT (2012). Effect of Aqueous and Ethanolic Extracts of Ocimum gratissimum on the Histology of the Spleen, Haematological Indicies of Wistar Rats and its Antimicrobial Properties. Asian Journal of Medical Sciences 4(4): 130-133.

Somogyi A, Rosta A, Lang I, Werling K (1996). Treatment of drug-induced bone marrow suppression with recombinant human granulocyte/monocyte colony stimulating factor. Adverse Drug React Toxicol Rev 15(2): 119-124.

Sule OJ, Godwin J, Nnopu IA (2012). Biochemical investigation of hepatotoxic effects of antiretroviral drugs on Wistar albino rats. J Phys Pharm Adv 2(4): 171-175.

Tadele A (2014). Prevalence of Zidovudine induced megaloblastic anemia among HIV/AIDS patients attending University of Gondar Hospital, Northwest Ethiopia. J Blood Disorders Transf 5(8): 143-148.

Ughachukwu PO, Okonkwo PO, Nwozor CM, Okafor IJ, Nwafia I (2016) .Effect of aqueous leaf extract of ocimum gratissimum on antiretroviral drug-induced hepatotoxicity in rats. EJMP 13(1): 1-11.

Uhegbu FO, Elekwa F, Akubugwo EI, Chinyere GC, Iweala EE (2012). Analgesic and hepatoprotective activity of methanolic leaf extract of Ocimum gratissimum. Research Journal of Medicinal Plants 6(1): 108-115.

Ukoha UU, Umeasalugo KE, Dimkpa U, Ndukwe G, Anyabolu AE, Emefo LE (2015). Effects of zidovudine on hemostatic and hematologic parameters in adult rats. J Exp Integr Med 5(2): 85-88.

Youm JW, Wom YS, Jeon JH, Moon KB, Kim HC, Shin KS, Young H, Kim HS (2010). Antibody responses in mice stimulated by various doses of the potato-derived major surface antigen of hepatitis B virus. Clin Vaccine Immunol 17(12): 2029-2032.

Cite this Article: Ughachukwu PO, Okonkwo PO, Nwozor CM, Okafor IJ, Nwafia IN, Ochiogu BC (2017). Effect of Aqueous Leaf Extract of Ocimum Gratissimum on some Haematological Indices in Rats Treated with Zidovudinecontaining Antiretroviral Drugs. Greener Journal of Medical Sciences, 7(2): 022-031, http://doi.org/10.15580/GJMS.2017.2.022717028 